\title{
Differential Expression of Genes Related to Sexual Determination Can Modify the Reproductive Cycle of Astyanax scabripinnis (Characiformes: Characidae) in B Chromosome Carrier Individuals
}

\author{
Jonathan Pena Castro ${ }^{1, *(\mathbb{D})}$, Ricardo Shohei Hattori ${ }^{2}{ }^{(0}$, Túlio Teruo Yoshinaga ${ }^{3}{ }^{(0)}$, \\ Duílio Mazzoni Zerbinato de Andrade Silva ${ }^{4}{ }^{(}$, Francisco J. Ruiz-Ruano ${ }^{5}$, Fausto Foresti ${ }^{4}$, \\ Mateus Henrique Santos ${ }^{6}$, Mara Cristina de Almeida ${ }^{6}(\mathbb{D})$, Orlando Moreira-Filho ${ }^{1}$ and \\ Roberto Ferreira Artoni ${ }^{1,6}$ \\ 1 Departamento de Genética e Evolução, Programa de Pós-Graduação em Biologia Evolutiva e Genética \\ Molecular, Universidade Federal de São Carlos, Rodovia Washington Luis, Km 235, Monjolinho, São Carlos, \\ SP 13565-905, Brazil; omfilho@ufscar.br (O.M.-F.); rfartoni@gmail.com (R.F.A.) \\ 2 Estação Experimental de Salmonicultura de Campos do Jordão, UPD-CJ (APTA/SAA), Campos do Jordão, \\ São Paulo, SP 12460-000, Brazil; hattori.fish@gmail.com \\ 3 Faculdade de Medicina Veterinária e Zootecnia da Universidade de São Paulo, Departamento de Cirurgia, \\ Universidade de São Paulo, Butantã, Rua Professor Orlando Marque Paiva, São Paulo, SP 05508-270, Brazil; \\ teruo92@gmail.com \\ 4 Departamento de Morfologia, Instituto de Biociências, Universidade Estadual Paulista, Distrito de Rubião \\ Junior, s/n, Botucatu, SP 18618-970, Brazil; duiliozerbinato@gmail.com (D.M.Z.d.A.S.); \\ fforesti@ibb.unesp.br (F.F.) \\ 5 Department of Ecology and Genetics, Evolutionary Biology Centre, Uppsala University, SE-752 36 Uppsala, \\ Sweden; francisco.ruiz-ruano@ebc.uu.se \\ 6 Departamento de Biologia Estrutural, Molecular e Genética, Programa de Pós-Graduação em Biologia \\ Evolutiva, Universidade Estadual de Ponta Grossa, Avenida Carlos Cavalcanti, 4748, Ponta Grossa, \\ PR 84030-900, Brazil; mateushenrique@yahoo.com.br (M.H.S.); almeidamara@uol.com.br (M.C.d.A.) \\ * Correspondence: jonathan.penacastro@gmail.com; Tel.: +55-42-3220-3739
}

Received: 4 October 2019; Accepted: 4 November 2019; Published: 8 November 2019

\begin{abstract}
The species complex Astyanax scabripinnis is one of the most studied with respect to origin, distribution, and frequency of B chromosomes, and is considered a model organism for evolutionary studies. Research using population inferences about the occurrence and frequency of the $B$ chromosome shows seasonal variation between sexes, which is associated with the presence of this supernumerary element. We hypothesized that the B chromosome could influence the sex ratio of these animals. Based on this assumption, the present work aimed to investigate if differences exist among levels of gene expression with qRT-PCR of the amh (associated with testicular differentiation) and foxl2a (associated with ovarian differentiation) genes between B-carrier and non-B-carrier individuals. The results showed that for the amh gene, the difference in expression between animals with $B$ chromosomes was not accentuated compared to that in animals without this chromosome. Expression of foxl2a in B-carrier females, however, was reduced by $73.56 \%$ compared to females that lacked the B chromosome. Males had no difference in expression of the amh and foxl2a genes between carriers and non-carriers of the $B$ chromosome. Results indicate that the presence of $\mathrm{B}$ chromosomes is correlated with the differential expression of sex-associated genes. An analysis of these results integrated with data from other studies on the reproductive cycle in the same species reveals that this difference in expression may be expanding the reproductive cycle of the species.
\end{abstract}

Keywords: fishes; supernumerary chromosomes; sexual differentiation; foxl2a; amh 


\section{Introduction}

The process that shapes sexual evolution and sex determination is one of the most interesting and fundamental aspects of the history of life. The sex development of several vertebrate groups has been described, which allows for the establishment of two mechanisms of sex determination: genetic (GSD) and environmental sex determination (ESD) [1]. In fish, genetic sex determination can be triggered primarily through the action of a master gene or various loci associated with sex, while environmental sex determination is regulated by external factors (e.g., water temperature), and a mixture of both mechanisms may act in sexually undifferentiated gonads [2]. However, in subsequent events, a shift can occur during sexual differentiation, such as sex inversion, where genotypic females and males develop as phenotypic males and females, respectively [3].

For a long time, the knowledge of sex determination in fish was associated with homologous genes related to sex development usually found in other species or more distant groups. Currently, some master genes of sex determination have been described related to male development, such as $d m y$ (Y-specific DM-domain) in Oryzias latipes, gsdfy (gonadal soma-derived growth factor on the $\mathrm{Y}$ chromosome) in Oryzias luzonensis, and $s d y$ (sexually dimorphic on the Y chromosome) in salmonids [4-6]. In addition, a second copy of the anti-Müllerian hormone gene, amhy (Y-linked anti-Müllerian hormone) has been described as a sex determinant gene in Odontesthes hatcheri, Odontesthes bonariensis, and Hypoatherina tsurugae [7-9]. Although fish do not have Müllerian ducts, elevated levels of amh expression were detected in the early stages of testis development in several teleosts [10-12]. Furthermore, in Oreochromis niloticus, amh was expressed at low levels in gonads before sexual differentiation in both $\mathrm{XX}$ and $\mathrm{XY}$ animals, and also presented dimorphic expression in males during germinative lineage differentiation [13], and a recent study reported a second copy of amh linked with the $\mathrm{Y}$ chromosome that might be a candidate as a sex determinant gene in Nile tilapia [14]. This data suggests that amh genes are strongly related to male gonad development in several fish species.

On the other hand, the transcription factor forkhead box like-2 (foxl2a) is associated with ovarian differentiation and the development of conserved features among vertebrates [13]. The foxl2 gene is the earliest detected gene expressed during ovarian development in mammals and other vertebrates. In mammals, foxl2 promotes ovarian development by upregulating aromatase expression, hence inducing estrogen production [15]. This mechanism has also been described in many teleosts. In addition, at least two isoforms have been described in several fish species (foxl2a and foxl2b) [16], such as Nile tilapia [17], zebrafish [18], and rainbow trout, supporting the conserved role of foxl2 during ovary development from fish to mammals.

Although functions related to $a m h$ and foxl2 have been described in many fish species, their role in sex development and sex determination in neotropical fish models remains unknown. Neotropical fish are a special group with more than 5000 known species [19]. Among them, the Astyanax genus (Baird and Girard, 1854) comprises a dominant group in South America, including at least 250 known species [20,21], Astyanax scabripinnis being one of the most studied [22]. Furthermore, a remarkable cytogenetic feature is the presence of $\mathrm{B}$ chromosomes equivalent in size to the first pair of karyotype complement in different allopatric populations [23]. In most populations, only one $\mathrm{B}$ chromosome per metaphase is consistently found in individuals, and all individuals carry exactly the same B chromosome [24]. Individuals carrying two B chromosomes are extremely rare [23].

The B chromosome comprises an additional genetic element found in all eukaryote groups, which do not pair with chromosomes of standard complement (chromosome A) during meiosis, exhibiting an irregular segregation that does not obey the Mendelian principles underlying the mechanisms of population accumulation [25]. Until recently, it was believed that B chromosomes did not carry functional genes and were not able to change the phenotype of the carrier organisms [25-27]. However, genes related to cellular division, the mitotic cycle, cellular metabolism, and nucleotide transcription, in which B chromosome transcripts were correlated in mammals and invertebrates, were recently reported [28-30]. In fish, B chromosome carrier males of A. scabripinnis presented higher levels of 
dmrt1 expression during the maturation stage [31]. In addition, a correlation of the sex ratio with $\mathrm{B}$ chromosome carrier individuals of $A$. scabripinnis was made, where seasonal distortions increased the sex ratio in favor of females [32-35]. Moreover, B-carrying females demonstrated a delay in the reproductive peak, suggesting a possible adaptive role of the B chromosome in the reproductive cycle [35].

Thus, based on previous studies, we hypothesized that B chromosome occurrence could influence the reproductive cycle of $A$. scabripinnis populations through the regulation of sex-development-related genes such as amh and foxl2a. Thus, our aim was to characterize the expression of amh and foxl $2 a$ genes between males and females and their relation to the presence of the $\mathrm{B}$ chromosome in A. scabripinnis individuals.

\section{Materials and Methods}

\subsection{Characterization of the Study Object}

We sampled 24 adult specimens (12 females, 12 males) of $A$. scabripinnis from Guaratinguetá (Fazenda Lavrinha), Estado de São Paulo, Brasil ( $\left.22^{\circ} 40^{\prime} 49.5^{\prime \prime} \mathrm{S}, 45^{\circ} 23^{\prime} 31.9^{\prime \prime} \mathrm{W}\right)$. They were captured actively with $0.5 \mathrm{~mm}$ mesh sieves and passively with covo-type traps during their reproductive cycle (November to January). Captured fish were conditioned in plastic bags with water and oxygen under pressure, then transported to the Estação Experimental de Salmonicultura (APTA/UDC-Campos do Jordão, São Paulo) for processing. All procedures were conducted in accordance with the guidelines of animal experimentation established by the Comissão de Ética em Pesquisa Animal da Universidade Estadual de Ponta Grossa (COEP-UEPG) with legal authorization provided by the Instituto Chico Mendes de Conservação da Biodiversidade (ICMBio— \# 15115-1).

\subsection{Cytogenetics}

Identification of animals with the B chromosome was achieved using the techniques described by Bertollo et al. [36]. Briefly, a microdissected B chromosome probe was amplified through a degenerate oligonucleotide primer. PCRs were performed with $1 \times$ Taq DNA Polymerase Buffer (Invitrogen), $2 \mathrm{mM}$ of $\mathrm{MgCl}_{2}, 40 \mu \mathrm{M}$ of dTTP, dGTP, and dCTP, $20 \mu \mathrm{M}$ of dATP, $20 \mu \mathrm{M}$ of digoxigenin-16-dUTP, $2 \mu \mathrm{M}$ of DOP primer, and $2 \mathrm{U}$ of Taq DNA polymerase. Amplification was performed under the following conditions: $3 \mathrm{~min}$ at $94{ }^{\circ} \mathrm{C}, 35$ cycles of $90 \mathrm{~s}$ at $90{ }^{\circ} \mathrm{C}, 90 \mathrm{~s}$ at $52{ }^{\circ} \mathrm{C}$, and $90 \mathrm{~s}$ at $72{ }^{\circ} \mathrm{C}$; followed by a post-cycling extension for $5 \mathrm{~min}$ at $72{ }^{\circ} \mathrm{C}$. The obtaining of mitotic chromosomes and fluorescent in situ hybridization (FISH) with a whole chromosome painting B probe was carried out according to Vicari et al. [37] and Cornelio et al. [35]. Hybridization occurred under high-stringency conditions ( $2.5 \mathrm{ng} / \mu \mathrm{L}$ probe, $50 \%$ formamide, $2 \times \cdot \mathrm{SSC}, 10 \%$ dextran sulfate). Signals were detected with the Anti-Digoxigenin-Rhodamine antibody (Roche, Mannheim, Germany). Materials were counterstained with ProLong Gold Antifade Mountant with DAPI (Thermo Fisher, Burlington, ON, Canada). Preparations were analyzed using an epifluorescence microscope (Olympus BX41, New York, NY, USA) coupled to an image capture system (CCD Olympus DP 71 and DP Controller v. 3.2.1.276).

\subsection{Histological Analysis}

Histological procedures were performed to confirm the individual sex and classification of the maturation stage of gonadal development. Gonad samples were dissected and fixed in Bouin solution for $24 \mathrm{~h}$ at room temperature. Samples were subsequently dehydrated, embedded in paraffin, sliced into sections of 3-5 $\mu \mathrm{m}$ thickness, and stained with hematoxylin and eosin. The gonads were classified in the mature state, based on the development stage, according to Vazzoler [38].

\subsection{RNA Extraction and cDNA Synthesis}

All the animals were kept in the same acclimation conditions in the laboratory ( $250 \mathrm{~L}$ tanks with constant aeration, controlled temperature at $25^{\circ} \mathrm{C}, 12 \mathrm{~h}$ light, and fed once a day for $48 \mathrm{~h}$ ) until tissue 
sample collection. After dissection, gonads were immediately fixed in RNAlater Solution (Ambion, Vilnius, Lithuania). Total RNA was extracted through homogenization in TRIzol (Invitrogen, Carlsbad, CA, USA) according to the manufacturer's instructions and purified with DNase I, Amplification Grade (Invitrogen). Total RNA concentration was measured by spectrophotometry and the integrity was verified by electrophoresis of $28 \mathrm{~S}$ and $18 \mathrm{~S}$ bands in $1 \%$ agarose gel. The cDNA was synthesized with $1 \mu \mathrm{g}$ of total RNA using Oligo(dT) ${ }_{12-18}$ Primer (Invitrogen) and reverse transcriptase was performed using SuperScript III (Invitrogen).

\subsection{Quantitative PCR in Real-Time ( $q R T-P C R)$}

We designed specific primers of the amh and foxl2 genes for qRT-PCR analysis in A. scabripinnis. First we got the sequences of amh (ENSAMXG00000032908) and foxl2a (ENSAMXG00000026282), amplifying by conventional PCR with primers designed from conserved regions (determined by comparison with the sequences of other fish species, i.e., Pygocentrus nattereri, Danio rerio, Ictalurus punctatus, Scleropages formosus, Cyprinus carpio) of the Astyanax mexicanus genome assembly (Accession GCA_000372685.1) by searching in the Ensembl database (http://www.ensembl.org/index.html). These sequences were the exon-exon junctions from the CDS (coding sequence) regions (Table 1). PCR reactions contained $1 \times$ PCR buffer, $1.5 \mathrm{mM} \mathrm{MgCl}$, $200 \mu \mathrm{M}$ dNTPs, $0.1 \mu \mathrm{M}$ of each primer (10 pmol), $0.5 \mathrm{U}$ Taq DNA Polymerase (Invitrogen), and $1 \mu \mathrm{L}$ (100 ng) of A. scabripinnis genomic DNA (obtained by saline extraction method, according to the protocol of Bruford [39]). We performed PCR amplification starting with $95{ }^{\circ} \mathrm{C}$ for $5 \mathrm{~min}$, followed by 35 cycles at $94{ }^{\circ} \mathrm{C}$ for $1 \mathrm{~min}, 51{ }^{\circ} \mathrm{C}$ for $45 \mathrm{~s}$, and $72{ }^{\circ} \mathrm{C}$ for $1 \mathrm{~min}$ and $20 \mathrm{~s}$, and a final extension of $72{ }^{\circ} \mathrm{C}$ for $5 \mathrm{~min}$. Products were purified using the High Pure PCR Cleanup Micro Kit (GE Healthcare Amersham Biosciences, Buckinghamshire, UK) and sequenced using an ABI PRISM ${ }^{\mathrm{TM}} 377$ DNA Sequencer (Perking-Elmer, Foster City, USA) with the DYEnamic ${ }^{\mathrm{TM}}$ ET Terminator Cycle Sequencing Kit (GE Healthcare Amersham Biosciences, Buckinghamshire, UK). We followed the manufacturer's instructions for both steps. After obtaining the sequences, A. scabripinnis specific primers were designed for qRT-PCR (Table 1). The entire procedure of alignment, primer construction, and BLASTn search was performed in Geneious R11's suite of molecular biology and NGS analysis tools.

Table 1. Designed primers used for conventional PCR and qRT-PCR.

\begin{tabular}{|c|c|c|}
\hline Gene & Primer Sequence $\left(5^{\prime}-3^{\prime}\right)$ & Use \\
\hline ame_amh_Fw1 & CTGGGATGTTGAAGACGA & Conventional PCR \\
\hline ame_amh_Rv1 & GAGGAATTAATCAGCTCCAGAA & Conventional PCR \\
\hline ame_fox2_Fw1 & ACGTTCTTGGGCTCAGAGGA & Conventional PCR \\
\hline ame_foxl2a_Rv1 & AGACTTGCCGGGTTGGAAGTG & Conventional PCR \\
\hline amh_rtf1 & ССТСАСТGСТСТTCСТGACG & qRT-PCR \\
\hline$a m h \_r t R 1$ & AAACACCCAACACAGCTTGC & qRT-PCR \\
\hline foxl2a_rtF1 & ACCTGAGCCTTAACGAGTGC & qRT-PCR \\
\hline foxl2a_rtR1 & ATGTCTTCACACGTCGGGTC & qRT-PCR \\
\hline$\beta$-actin $F \_R T$ & ATCATGAAGTGCGACGTGGA & qRT-PCR \\
\hline$\beta$-actin $R \_R T$ & TATTTACGCTCAGGTGGGGC & qRT-PCR \\
\hline
\end{tabular}

The number of individuals utilized in each sample group is summarized in Table 2. The qRT-PCR was performed in the thermocycler Stratagene Mx3005P (Agilent Technologies, Waldbronn, Germany) using SYBR Select Master Mix (Life, Vilnius, Lithuania) in a final volume of $12.7 \mu \mathrm{L}$, with $2 \mu \mathrm{L}$ of cDNA in each reaction and $0.4 \mu \mathrm{L}$ of each primer $(10 \mathrm{mM})$. The thermal profile was $95{ }^{\circ} \mathrm{C}$ for $10 \mathrm{~min}$, followed by 40 cycles at $95^{\circ} \mathrm{C}$ for $40 \mathrm{~s}$, and $60^{\circ} \mathrm{C}$ for $1 \mathrm{~min}$ for both genes. After amplification, the dissociation step was realized by increasing the temperature from $60{ }^{\circ} \mathrm{C}$ to $95{ }^{\circ} \mathrm{C}$ in order to create a melting curve and ensure the presence of only the amplification product. Samples without $\mathrm{Ct}$ values or with inconsistent $\mathrm{Ct}$ values between replicas (difference $\mathrm{Ct}>2$ cycles) were excluded from the analysis. 
Table 2. Individual samples used in gene expression analysis.

\begin{tabular}{|c|c|c|c|c|c|}
\hline Gene & $q(\mathbf{B}+)$ & $q(\mathbf{B}-)$ & $\sigma^{\prime}(\mathrm{B}+)$ & $\sigma^{x}(\mathrm{~B}-)$ & Total \\
\hline$a m h$ & 3 & 3 & 3 & 3 & 12 \\
\hline foxl $2 a$ & 3 & 3 & 3 & 3 & 12 \\
\hline Total & & & & & 24 \\
\hline
\end{tabular}

The qPCR data were obtained by MxPro software (Agilent Technologies) and normalized against values of $\beta$-actin and the quantification obtained by a $2^{-\Delta \Delta C T}$ method [40]. The values were submitted to the normality test (Shapiro-Wilk normality test) and homoscedastic variance analysis (Breusch-Pagan test). The qPCR values were presented as the mean \pm standard error of the mean (SEM) and analyzed by ANOVA one way, the Student's $t$-test, and Tukey's test with significant values at $p<0.05$ (Supplementary Table S1), in GraphPad Prism 7 software.

\subsection{Illumina Sequencing and Coverage Analysis of Sex-Associated Genes}

The presence of amh and foxl2a genes in the A. scabripinnis B chromosome was determined by comparing the coverage patterns between three individuals without $B$ and another three with $B$ in gDNA Illumina HiSeq X Ten libraries, paired-end reads of $2 \times 150 \mathrm{nt}$. The genome coverage was calculated assuming that the genome size of A. scabripinnis is $1.87 \mathrm{~Gb}$ (Table 3) [41]. As reference for the amh and foxl2a genes, we used the sequences in A. mexicanus with Genbank accession numbers XM_022669774 and XM_007232295, respectively. First, we extracted similar reads from the CDSs and reconstructed their sequences specifically to $A$. scabripinnis using customized scripts (github.com/fjruizruano/whatGene/ blob/master/scripts/mapping_blat_gs.py, option nomap) with the option of considering mapping of at least $40 \mathrm{nt}$ with a minimum identity of $80 \%$. Then, we mapped the reads of each library on the CDSs through the SSAHA2 software [42] with a minimum alignment score of 40 and $80 \%$ minimum identity and obtained the abundance estimate in each library by counting the reads mapped by a custom script (github.com/fjruizruano/whatGene/blob/master/scripts/mapping_blat_gs.py, option ssaha2). Finally, we estimated the abundance per nucleotide position for each CDS in the B- and B+ genomes using a custom script (github.com/fjruizruano/ngs-protocols/blob/master/bam_coverage_join.py) and graphics were made with a custom script (github.com/fjruizruano/whatGene/blob/master/scripts/coverage_ graphics.py).

Table 3. Genome coverage and samples of Illumina sequencing.

\begin{tabular}{ccccc}
\hline Sex & Samples & Number of B & Number of Reads (mi) & Coverage \\
\hline Male & 2 & 0 & 93.7 & 7.5 \\
& 1 & 1 & 52.2 & 4.2 \\
\hline \multirow{2}{*}{ Female } & 1 & 0 & 43.7 & 3.5 \\
& 2 & 1 & 96 & 7.7 \\
\hline
\end{tabular}

\section{Results}

\subsection{Histological Analysis and Cytogenetics}

Histological analysis revealed the phenotypic sex and gonad maturation stages of the analyzed individuals (Figure 1a,b). In situ hybridization revealed the presence of the $\mathrm{B}$ chromosome in three females of $A$. scabripinnis, while seven males were observed with an occurrence of the B chromosome (Figure 1c,d).

\subsection{Analysis of Gene Expression of Amh and Foxl2a}

Gonads of analyzed individuals showed significant bimodal expression $(p$-value $<0.05)$ for the amh gene between males and females, independent of the presence of the B chromosome (Figure 2, Supplementary Table S1). Samples of gonadal tissue were analyzed for foxl2a gene expression. This 
analysis revealed significant differences of bimodal expression between females with B chromosomes and other groups. The number of females with B chromosomes was reduced by $73.56 \%$ compared to females that lacked the B chromosome (Figure 2, Supplementary Table S1).
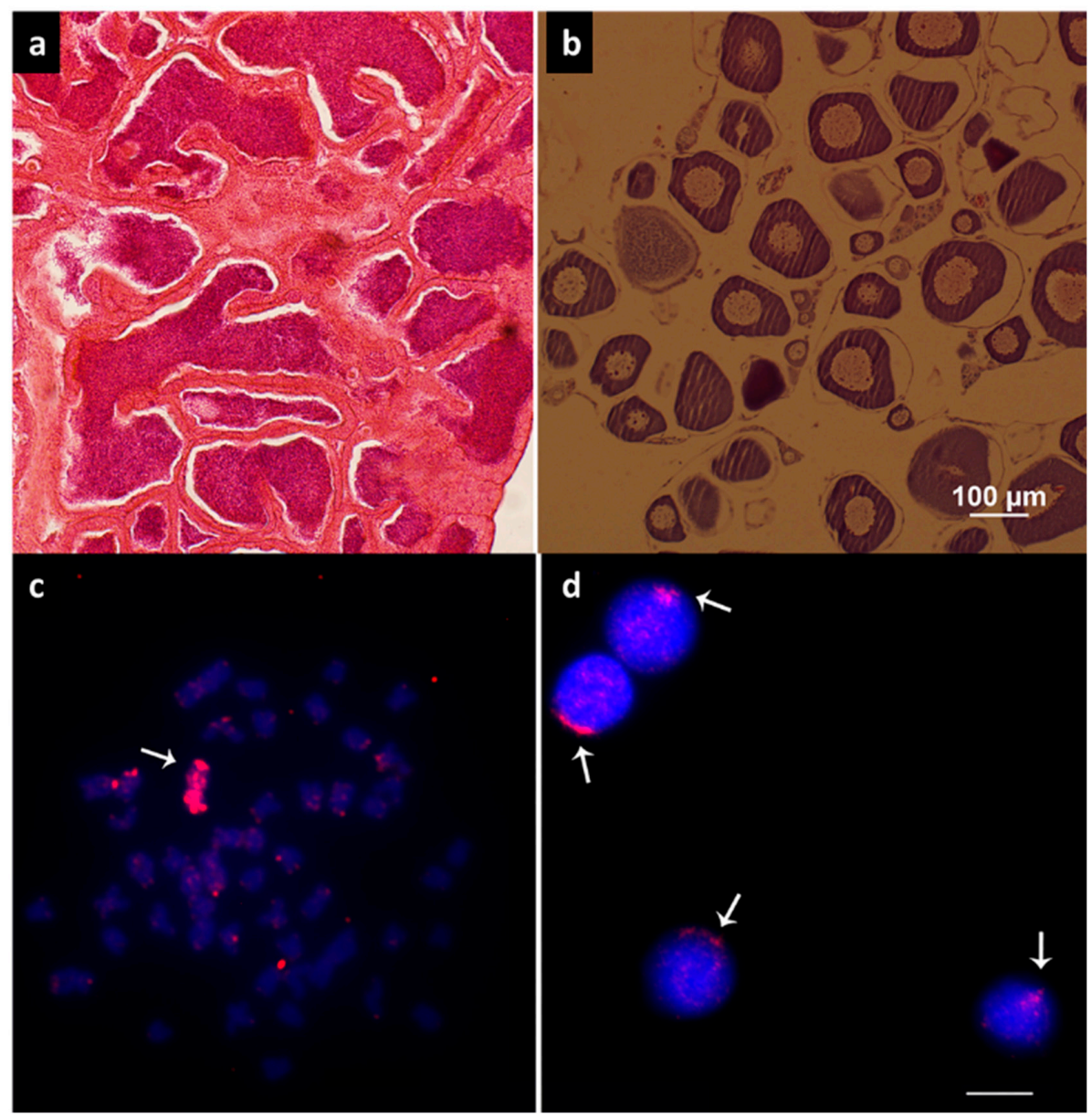

Figure 1. Histological sections of $A$. scabripinnis gonads. (a) Male. (b) Female. (c) Fluorescent in situ hybridization (FISH) with B chromosome probe in metaphasis and (d) nuclei, respectively. Arrows indicate the B chromosome probe signal. Bar: $10 \mu \mathrm{m}$.
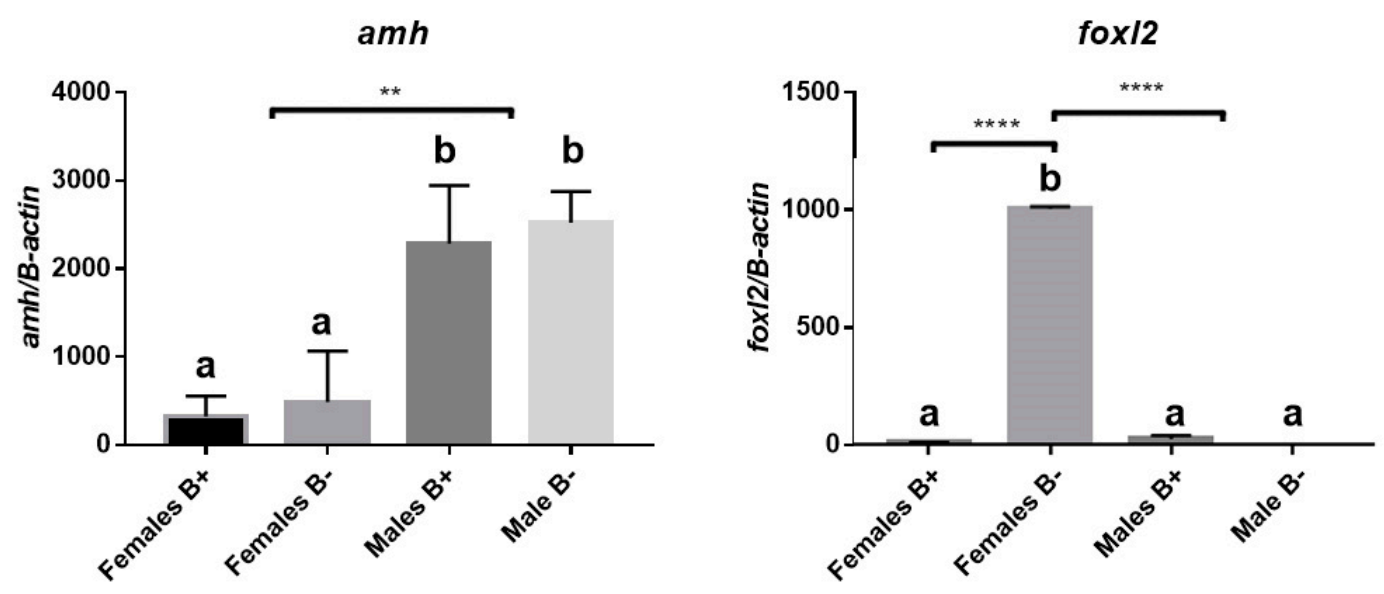

Figure 2. Relative expression levels of $a m h$ and foxl2a of adult A. scabripinnis. Groups that are significantly different from each other are represented by different letters ( $a$ and $b)$. $(B+)$ individuals with and (B-) without the B chromosome, respectively. ${ }^{* * *} p<0.0001$, extremely significant; ${ }^{* *} p 0.001$ to 0.01 , very significant. 


\subsection{Number of Gene Copies between Individuals with and without B Chromosomes}

The coverage analysis of libraries B- and B+ along with CDSs of the amh and foxl2a genes revealed no differences between groups in any of the genes analyzed (Figure 3). Although the graph shows some regions with differences in coverage between groups, there is clearly no uniformity. Thus, we infer that these genes are not present in the B chromosome of this population.

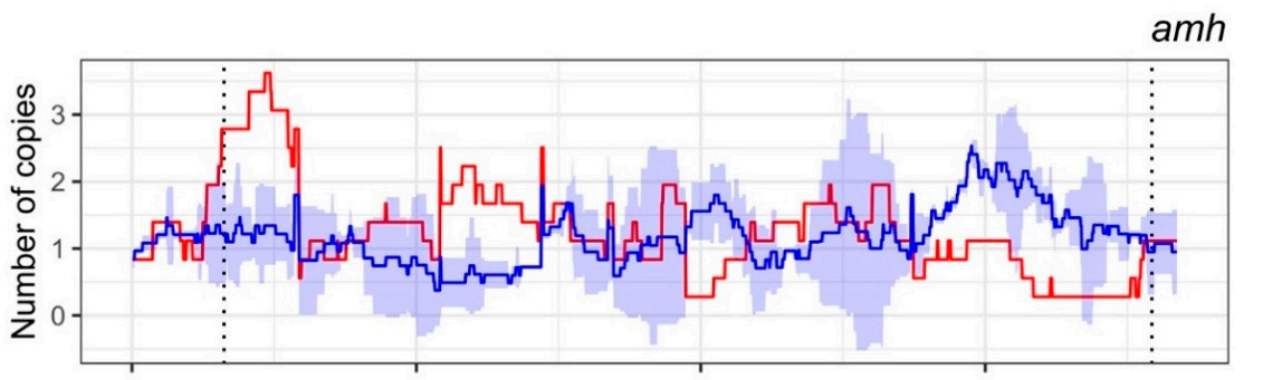

Male

- B-

$-B+$

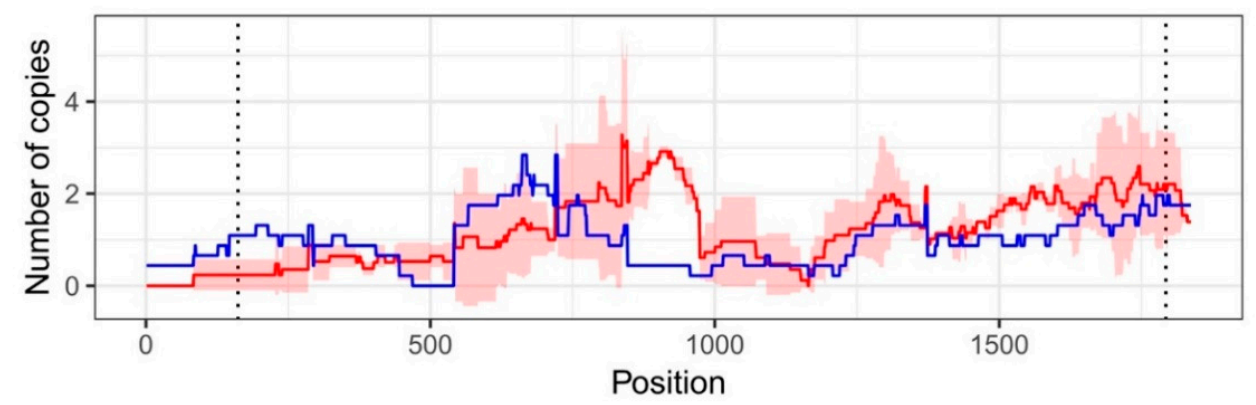

Female

$-\mathbf{B}-$

fox 12

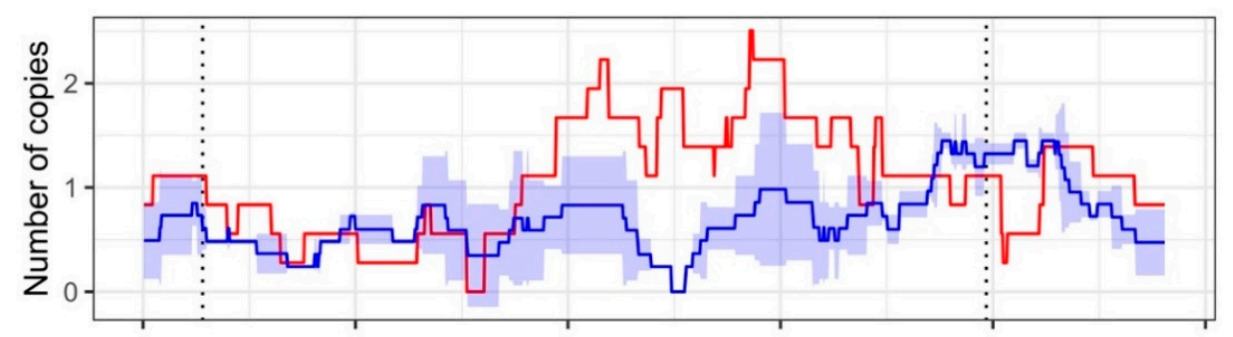

Male

- B-

$-\mathbf{B +}$

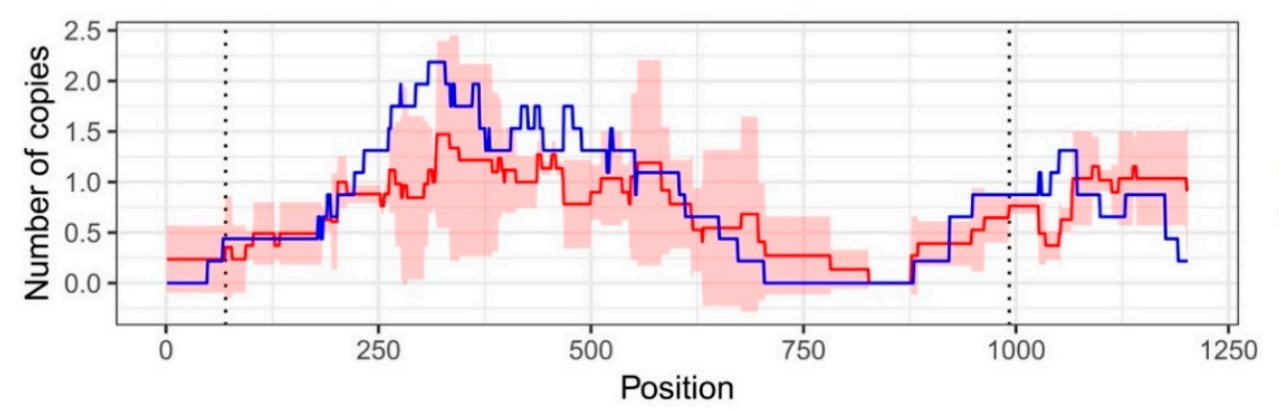

Female

- B-

Figure 3. Comparison of the number of copies of the amh and foxl2a genes in gDNA of individuals with $(\mathrm{B}+)$ and without the $\mathrm{B}$ chromosome (B-). The dotted line is the limit of the coding sequence (CDS). The $p$-value $(p<0.05)$ between copy number was not significantly different $(p=0.8509$ and 0.7333 for the $t$-test of male and female $a m h$, respectively, and $p=0.2979$ and 0.7752 for the $t$-test of male and female foxl2a, respectively).

\section{Discussion}

Neotropical fish species comprise an interesting group with a considerable variety of physiological and reproductive mechanisms. In addition, some species such as $A$. scabripinnis have the B chromosome, 
a remarkable cytogenetic characteristic that recently demonstrated roles in diverse cellular functions. This study is a pioneer in analyzing the expression of amh and foxl2a genes in male and female gonads of fish and the influence of the B chromosome's presence. Here we demonstrated that the amh gene presented a dimorphic expression between females and males of $A$. scabripinnis independent of the presence of the B chromosome. Furthermore, foxl $2 a$ also presented a dimorphic expression between females and males, but B+ females presented a lower expression of foxl $2 a$ compared to a B- female, suggesting a regulatory effect of the $\mathrm{B}$ chromosome in foxl $a$ expression during the reproductive period in $\mathrm{B}+$ females.

The higher expression of amh in males compared to females is consistent with other reported studies. Amh plays important roles in sex determination, testis development during embryonic stages, and spermatogenesis in many teleost fishes [43]. Amh function in fish is supposed to act as an aromatase inhibitor like it does in mammals, hence inhibiting estrogen production during testis development and spermatogenesis [7]. However, this relation is not well established since other studies have demonstrated independent expression of aromatase and $a m h$ in other species $[11,44,45]$. Nevertheless, second copies of the amh gene were not detected in the B chromosome of $A$. scabripinnis and their expression did not differ between $\mathrm{B}+$ or B- males.

Although the B chromosome apparently did not affect amh expression, this was not the case with foxl2a. B+ females presented an atypical expression of foxl2a compared to a B- female. Foxl $2 a$ has been associated with ovarian development in all studied species (revisited in Bertho et al. [16]), demonstrating clearly high expression in females compared to males, which is conserved condition for this gene among teleost fishes [13]. Nevertheless, although other copies of foxl $2 a$ were not found in B+ sequenced females, other factors might regulate gene expression. Some studies suggest transcription regulation of $\mathrm{A}$ chromosome genes by non-coding mRNA in the B chromosome in cichlid fish and insects $[46,47]$. In addition, previous studies reported over-expression of the $d m r t 1$ gene expression in $\mathrm{B}+$ male during the maturation stage [31]. Thus, the $\mathrm{B}$ chromosome may have some regulatory role on foxl2a expression in A. scabripinnis females, and such regulatory effect of the B chromosome on sex development genes could be responsible for the uncharacteristic reproductive period of $\mathrm{B}+$ individuals, and also the disproportional sex ratio reported [32,34,48,49].

Studies on the reproductive cycle in this species demonstrated that B-females have reproductive activity from July to December, while B+ females present a reproductive peak shorter and later, from December to February [35]. This regulatory effect could cause, in the case of females, later ovary development, since B+ females presented lower expression of foxl2a compared to a B- female, and extending male spermatogenesis due to the upregulatory effect on $d m r t 1$ expression reported for B+ males of A. scabripinnis [31] (Figure 4). Such an extended reproductive period may contribute to the maintenance of this chromosome and consist of an important adaptive advantage that maintains populations in small high-altitude streams, which are constantly susceptible to intense environmental variations and predation [35,50,51]. Regarding a disproportional sex ratio, our sampling did not demonstate such a difference, mainly because we chose not to do that. Nevertheless, the B chromosome could also regulate sex development genes during embryonic stages, increasing the number of females. However, the sex ratio can be altered by environmental factors or endocrine disruptors, as demonstrated in several fish species, and the B chromosome is likely not involved [52,53].

In summary, these results highlight that the presence of the B chromosome significantly alters the expression profile of major sex-linked genes, indicating the adaptive relevance of this chromosome, directly influencing the reproductive cycle dynamic of these animals and expanding the reproduction period, enabling the generation of a greater number of offspring. Although we did not detect second copies of analyzed genes in the B chromosome, regulatory effects could occur in B-carrier animals through non-coding mRNA, transposons, or even microRNAs. However, how the B chromosome regulates these genes in $A$. scabripinnis requires further investigation, and novel techniques with B-omics will help us understand the genetic, transcriptional, epigenetic, and protein functions involved in cellular biology and their relation to sex development [28]. 


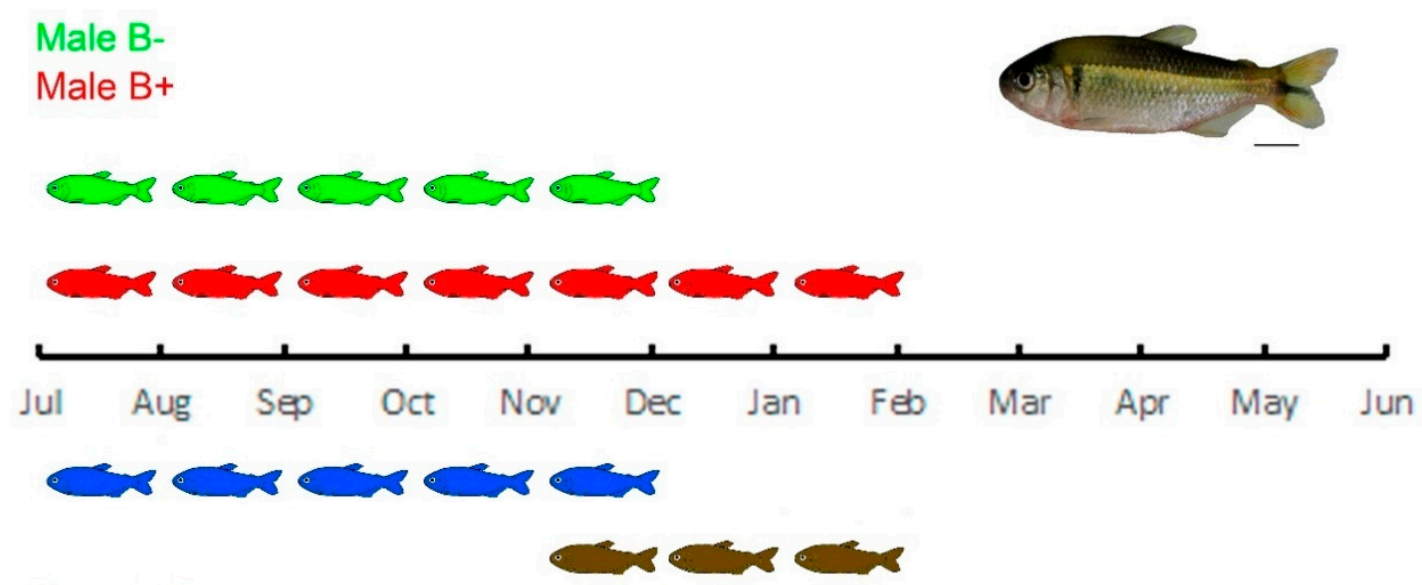

\section{Female B-}

Female $\mathrm{B}^{+}$

Figure 4. Representation and data of the reproductive period of $A$. scabripinnis, according to [31,35]. $\mathrm{B}-$ : without $\mathrm{B}$ chromosome, $\mathrm{B}+$ : with $\mathrm{B}$ chromosome. It is important to highlight the late reproductive activity of females with B chromosomes and the extension of males carrying the additional chromosome, which allows them to reproduce with females with or without B chromosomes throughout the period, ensuring the maintenance of this chromosome in the population. Fish bar: $1 \mathrm{~cm}$.

Supplementary Materials: The following are available online at http://www.mdpi.com/2073-4425/10/11/909/s1: Table S1: Statistical analysis $(p<0.05)$ for amh and foxl2a genes.

Author Contributions: Conceptualization, R.F.A.; Data curation, J.P.C., T.T.Y. and F.J.R.-R.; Formal analysis, R.S.H., D.M.Z.d.A.S., F.F., M.H.S. and R.F.A.; Investigation, J.P.C., T.T.Y. and R.F.A.; Methodology, R.S.H., F.J.R.-R. and R.F.A.; Software, F.J.R.-R.; Supervision, R.F.A.; Validation, R.S.H.; Visualization, D.M.Z.d.A.S., F.F., M.H.S., M.C.d.A. and O.M.-F.; Writing—original draft, J.P.C. and R.F.A.; Writing—review \& editing, J.P.C. and R.F.A.

Funding: This research was funded by Conselho Nacional de Desenvolvimento Científico e Tecnológico (CNPq) grant number 407187/2016-2, Coordenação de Aperfeiçoamento de Pessoal de Nível Superior (CAPES), finance code 001 and Fundação Araucária (Fundação Araucária de Apoio ao Desenvolvimento Científico e Tecnológico do Estado do Paraná, Grant number 16174).

Acknowledgments: The authors acknowledge the Instituto Chico Mendes de Conservação da Biodiversidade (ICMBio). We thank Juan Pedro M Camacho for his suggestions and attention.

Conflicts of Interest: The authors declare no conflict of interest.

\section{References}

1. Trukhina, A.V.; Lukina, N.A.; Wackerow-Kouzova, N.D.; Smirnov, A.F. The variety of vertebrate mechanisms of sex determination. BioMed Res. Int. 2013, 2013, 587460. [CrossRef] [PubMed]

2. Devlin, R.H.; Nagahama, Y. Sex determination and sex differentiation in fish: An overview of genetic, physiological, and environmental influences. Aquaculture 2002, 208, 191-364. [CrossRef]

3. Martínez, P.; Viñas, A.M.; Sánchez, L.; Díaz, N.; Ribas, L.; Piferrer, F. Genetic architecture of sex determination in fish: Applications to sex ratio control in aquaculture. Front. Genet. 2014, 5, 340. [CrossRef] [PubMed]

4. Matsuda, M.; Nagahama, Y.; Shinomiya, A.; Sato, T.; Matsuda, C.; Kobayashi, T.; Morrey, C.E.; Shibata, N.; Asakawa, S.; Shimizu, N.; et al. DMY is a Y-specific DM-domain gene required for male development in the medaka fish. Nature 2002, 417, 559-563. [CrossRef] [PubMed]

5. Myosho, T.; Otake, H.; Masuyama, H.; Matsuda, M.; Kuroki, Y.; Fujiyama, A.; Naruse, K.; Hamaguchi, S.; Sakaizumi, M. Tracing the emergence of a novel sex-determining gene in medaka, Oryzias luzonensis. Genetics 2012, 191, 163-170. [CrossRef]

6. Yano, A.; Nicol, B.; Jouanno, E.; Quillet, E.; Fostier, A.; Guyomard, R.; Guiguen, Y. The sexually dimorphic on the $\mathrm{Y}$-chromosome gene $(s d Y)$ is a conserved male-specific $\mathrm{Y}$-chromosome sequence in many salmonids. Evol. Appl. 2013, 6, 486-496. [CrossRef] 
7. Hattori, R.S.; Murai, Y.; Oura, M.; Masuda, S.; Majhi, S.K.; Sakamoto, T.; Fernandino, J.I.; Somoza, G.M.; Yokota, M.; Strussmann, C.A. A Y-linked anti-Mullerian hormone duplication takes over a critical role in sex determination. Proc. Natl. Acad. Sci. USA 2012, 109, 2955-2959. [CrossRef]

8. Yamamoto, Y.; Zhang, Y.; Sarida, M.; Hattori, R.S.; Strüssmann, C.A. Coexistence of Genotypic and Temperature-Dependent Sex Determination in Pejerrey Odontesthes bonariensis. PLoS ONE 2014, 9, e102574. [CrossRef]

9. Bej, D.K.; Miyoshi, K.; Hattori, R.S.; Strüssmann, C.A.; Yamamoto, Y. A Duplicated, Truncated amh Gene Is Involved in Male Sex Determination in an Old World Silverside. G3 Genes Genomes Genet. 2017, 7, 2489-2495. [CrossRef]

10. Yamaguchi, T.; Yoshinaga, N.; Yazawa, T.; Gen, K.; Kitano, T. Cortisol Is Involved in Temperature-Dependent Sex Determination in the Japanese Flounder. Endocrinology 2010, 151, 3900-3908. [CrossRef]

11. Haugen, T.; Almeida, F.F.; Andersson, E.; Bogerd, J.; Male, R.; Skaar, K.S.; Schulz, R.W.; Sørhus, E.; Wijgerde, T.; Taranger, G.L. Sex differentiation in Atlantic cod (Gadus morhua L.): Morphological and gene expression studies. Reprod. Biol. Endocrinol. 2012, 10, 47. [CrossRef] [PubMed]

12. Mankiewicz, J.L.; Godwin, J.; Holler, B.L.; Turner, P.M.; Murashige, R.; Shamey, R.; Daniels, H.V.; Borski, R.J. Masculinizing Effect of Background Color and Cortisol in a Flatfish with Environmental Sex-Determination. Integr. Comp. Biol. 2013, 53, 755-765. [CrossRef] [PubMed]

13. Siegfried, K.R. In search of determinants: Gene expression during gonadal sex differentiation. J. Fish Biol. 2010, 76, 1879-1902. [CrossRef] [PubMed]

14. Eshel, O.; Shirak, A.; Dor, L.; Band, M.; Zak, T.; Markovich-Gordon, M.; Chalifa-Caspi, V.; Feldmesser, E.; Weller, J.I.; Seroussi, E.; et al. Identification of male-specific amh duplication, sexually differentially expressed genes and microRNAs at early embryonic development of Nile tilapia (Oreochromis niloticus). BMC Genom. 2014, 15, 774. [CrossRef] [PubMed]

15. Pannetier, M. FOXL2 activates P450 aromatase gene transcription: Towards a better characterization of the early steps of mammalian ovarian development. J. Mol. Endocrinol. 2006, 36, 399-413. [CrossRef] [PubMed]

16. Bertho, S.; Pasquier, J.; Pan, Q.; Le Trionnaire, G.; Bobe, J.; Postlethwait, J.H.; Pailhoux, E.; Schartl, M.; Herpin, A.; Guiguen, Y. Foxl2 and Its Relatives Are Evolutionary Conserved Players in Gonadal Sex Differentiation. Sex. Dev. 2016, 10, 111-129. [CrossRef]

17. Zhang, X.; Li, M.; Ma, H.; Liu, X.; Shi, H.; Li, M.; Wang, D. Mutation of foxl2 or cyp19a1a results in female to male sex reversal in XX Nile tilapia. Endocrinology 2017, 158, 2634-2647. [CrossRef]

18. Caulier, M.; Brion, F.; Chadili, E.; Turies, C.; Piccini, B.; Porcher, J.M.; Guiguen, Y.; Hinfray, N. Localization of steroidogenic enzymes and Foxl2a in the gonads of mature zebrafish (Danio rerio). Comp. Biochem. Physiol. Part A Mol. Integr. Physiol. 2015, 188, 96-106. [CrossRef]

19. Reis, R.E.; Albert, J.S.; Di Dario, F.; Mincarone, M.M.; Petry, P.; Rocha, L.A. Fish biodiversity and conservation in South America. J. Fish Biol. 2016, 89, 12-47. [CrossRef]

20. Gery, J. Characoids of the World; TFH Publications: Neptune, NJ, USA, 1977.

21. Eschemeyer, W. Catalog of Fishes: Genera, Species, References. Available online: http://researcharchive. calacademy.org/research/ichthyology/catalog/fishcatmain.asp (accessed on 16 March 2018).

22. Tenorio, R.C.C.D.O.; Vitorino, C.D.A.; Souza, I.L.; Oliveira, C.; Venere, P.C. Comparative cytogenetics in Astyanax (Characiformes: Characidae) with focus on the cytotaxonomy of the group. Neotrop. Ichthyol. 2013, 11, 553-564. [CrossRef]

23. Salvador, L.B.; Moreira-Filho, O. B chromosomes in Astyanax scabripinnis (Pisces, Characidae). Heredity. 1992, 69, 50-56. [CrossRef]

24. Moreira-Filho, O.; Galetti, P.M.; Bertollo, L.A.C. B chromosomes in the fish Astyanax scabripinnis (Characidae, Tetragonopterinae): An overview in natural populations. Cytogenet. Genome Res. 2004, 106, 230-234. [CrossRef] [PubMed]

25. Camacho, J.P.M. B chromosomes. In The Evolution of the Genome; Gregory, T.R., Ed.; Elsevier Academic Press: London, UK, 2005; pp. 223-286. ISBN 0123014638.

26. Banaei-Moghaddam, A.M.; Martis, M.M.; Macas, J.; Gundlach, H.; Himmelbach, A.; Altschmied, L.; Mayer, K.F.X.; Houben, A. Genes on B chromosomes: Old questions revisited with new tools. Biochim. Biophys. Acta 2015, 1849, 64-70. [CrossRef] [PubMed]

27. Camacho, J.P.M.; Sharbel, T.F.; Beukeboom, L.W. B-chromosome evolution. Philos. Trans. R. Soc. Lond. Ser. B Biol. Sci. 2000, 355, 163-178. [CrossRef] [PubMed] 
28. Ahmad, S.; Martins, C. The modern view of b chromosomes under the impact of high scale omics analyses. Cells 2019, 8, 156. [CrossRef] [PubMed]

29. Navarro-Domínguez, B.; Ruiz-Ruano, F.J.; Cabrero, J.; Corral, J.M.; López-León, M.D.; Sharbel, T.F.; Camacho, J.P.M. Protein-coding genes in B chromosomes of the grasshopper Eyprepocnemis plorans. Sci. Rep. 2017, 7, 45200. [CrossRef]

30. Makunin, A.I.; Dementyeva, P.V.; Graphodatsky, A.S.; Volobouev, V.T.; Kukekova, A.V.; Trifonov, V.A. Genes on B chromosomes of vertebrates. Mol. Cytogenet. 2014, 7, 99. [CrossRef]

31. Castro, J.P.; Hattori, R.S.; Yoshinaga, T.T.; Silva, D.M.Z.D.A.; Foresti, F.; Santos, M.H.; Almeida, M.C.; Artoni, R.F. Differential Expression of dmrt1 in Astyanax scabripinnis (Teleostei, Characidade) Is Correlated with B Chromosome Occurrence. Zebrafish 2018, 16, 182-188. [CrossRef]

32. Vicente, V.E.; Moreira-Filho, O.; Camacho, J.P. Sex-ratio distortion associated with the presence of a B chromosome in Astyanax scabripinnis (Teleostei, Characidae). Cytogenet. Cell Genet. 1996, 74, 70-75. [CrossRef]

33. Silva, D.M.Z.D.A.; Pansonato-Alves, J.C.; Utsunomia, R.; Araya-Jaime, C.; Ruiz-Ruano, F.J.; Daniel, S.N.; Hashimoto, D.T.; Oliveira, C.; Camacho, J.P.M.; Porto-Foresti, F.; et al. Delimiting the Origin of a B Chromosome by FISH Mapping, Chromosome Painting and DNA Sequence Analysis in Astyanax paranae (Teleostei, Characiformes). PLoS ONE 2014, 9, e94896. [CrossRef]

34. Porto-Foresti, F.; Oliveira, C.; Maistro, E.L.; Foresti, F. Estimated frequency of B-chromosomes and population density of Astyanax scabripinnis paranae in a small stream. Braz. J. Genet. 1997, 20. [CrossRef]

35. Cornelio, D.; Castro, J.P.; Santos, M.H.; Vicari, M.R.; de Almeida, M.C.; Moreira-Filho, O.; Camacho, J.P.M.; Artoni, R.F. Hermaphroditism can compensate for the sex ratio in the Astyanax scabripinnis species complex (Teleostei: Characidae): Expanding the B chromosome study model. Rev. Fish Biol. Fish. 2017, 27, 681-689. [CrossRef]

36. Bertollo, L.A.C.; Takahashi, C.S.; Moreira-Filho, O. Cytotaxonomic considerations on Hoplias lacerdae (Pisces, Erythrinidae). Braz. J. Genet. 1978, 1, 103-120.

37. Vicari, M.R.; de Pistune Mello, H.F.; Castro, J.P.; de Almeida, M.C.; Bertollo, L.A.C.; Moreira-Filho, O.; Camacho, J.P.M.; Artoni, R.F. New insights on the origin of B chromosomes in Astyanax scabripinnis obtained by chromosome painting and FISH. Genetica 2011, 139, 1073-1081. [CrossRef] [PubMed]

38. Vazzoler, A.E.A.M. Biologia da Reprodução de Peixes Teleósteos: Teoria e Prática; EDUEM: Maringá, Brazil, 1996.

39. Bruford, M.W.; Hanotte, O.; Brookfield, J.F.Y.; Burke, T. Single-locus and multilocus DNA fingerprinting. In Molecular Genetics Analyses of Populations: A Practical Approach; HoelzelL, A.R., Ed.; IRL Press: Oxford, UK, 1992; pp. 225-269. ISBN 0-19-963277-4.

40. Livak, K.J.; Schmittgen, T.D. Analysis of Relative Gene Expression Data Using Real-Time Quantitative PCR and the $2^{-\Delta \Delta C}$ T Method. Methods 2001, 25, 402-408. [CrossRef]

41. Carvalho, M.L.; Oliveira, C.; Foresti, F. Nuclear DNA content of thirty species of Neotropical fishes. Genet. Mol. Biol. 1998, 21, 47-54. [CrossRef]

42. Spargo, A.; Ponstingl, H.; Ning, Z. SSAHA2: Sequence Search and Alignment by Hashing Algorithm. Available online: https://www.sanger.ac.uk/science/tools/ssaha2-0 (accessed on 16 March 2018).

43. Pfennig, F.; Standke, A.; Gutzeit, H.O. The role of Amh signaling in teleost fish-Multiple functions not restricted to the gonads. Gen. Comp. Endocrinol. 2015, 223, 87-107. [CrossRef]

44. Poonlaphdecha, S.; Pepey, E.; Canonne, M.; de Verdal, H.; Baroiller, J.F.; D'Cotta, H. Temperature induced-masculinisation in the Nile tilapia causes rapid up-regulation of both dmrt1 and amh expressions. Gen. Comp. Endocrinol. 2013, 193, 234-242. [CrossRef]

45. Morinaga, C.; Saito, D.; Nakamura, S.; Sasaki, T.; Asakawa, S.; Shimizu, N.; Mitani, H.; Furutani-Seiki, M.; Tanaka, M.; Kondoh, H. The hotei mutation of medaka in the anti-Mullerian hormone receptor causes the dysregulation of germ cell and sexual development. Proc. Natl. Acad. Sci. USA 2007, 104, 9691-9696. [CrossRef]

46. Li, Y.; Jing, X.A.; Aldrich, J.C.; Clifford, C.; Chen, J.; Akbari, O.S.; Ferree, P.M. Unique sequence organization and small RNA expression of a "selfish" B chromosome. Chromosoma 2017, 126, 753-768. [CrossRef]

47. Ramos, É.; Cardoso, A.L.; Brown, J.; Marques, D.F.; Fantinatti, B.E.A.; Cabral-de-Mello, D.C.; Oliveira, R.A.; O'Neill, R.J.; Martins, C. The repetitive DNA element BncDNA, enriched in the B chromosome of the cichlid fish Astatotilapia latifasciata, transcribes a potentially noncoding RNA. Chromosoma 2017, 126, 313-323. [CrossRef] [PubMed] 
48. Maistro, E.L.; Foresti, F.; Oliveira, C. New Occurrence of a Macro-B-Chromosome in Astyanax-ScabripinnisParanae (Pisces, Characiformes, Characidae). Braz. J. Genet. 1994, 17, 153-156.

49. Silva, D.M.Z.D.A.; Utsunomia, R.; Ruiz-Ruano, F.J.; Oliveira, C.; Foresti, F. The complete mitochondrial genome sequence of Astyanax paranae (Teleostei: Characiformes). Mitochondrial DNA Part B 2016, 1, 586-587. [CrossRef]

50. Castro, J.P.; Moura, M.O.; Moreira-Filho, O.; Shibatta, O.A.; Santos, M.H.; Nogaroto, V.; Vicari, M.R.; de Almeida, M.C.; Artoni, R.F. Diversity of the Astyanax scabripinnis species complex (Teleostei: Characidae) in the Atlantic Forest, Brazil: Species limits and evolutionary inferences. Rev. Fish Biol. Fish. 2015, 25, 231-244. [CrossRef]

51. Castro, J.P.; Moura, M.O.; Moreira-Filho, O.; Shibatta, O.A.; Santos, M.H.; Nogaroto, V.; Vicari, M.R.; de Almeida, M.C.; Artoni, R.F. Evidence of incipient speciation in Astyanax scabripinnis species complex (Teleostei: Characidae). Neotrop. Ichthyol. 2014, 12, 429-438. [CrossRef]

52. Pandian, T.J. Sexuality in Fishes; Science Publishers Enfield/CRC Press: New Hampshire, UK, 2010; ISBN 9781578086856.

53. Pandian, T.J. Genetic Sex Differentiation in Fish; Science Publishers Enfield/CRC Press: New Hampshire, UK, 2012; ISBN 9781466517103.

(C) 2019 by the authors. Licensee MDPI, Basel, Switzerland. This article is an open access article distributed under the terms and conditions of the Creative Commons Attribution (CC BY) license (http://creativecommons.org/licenses/by/4.0/). 